\title{
Spiritual And Legal Basis For Improving The Relationship Of National Folk Crafts And Unity Of Traditions
}

\author{
Norova Orifa Zulfiqorovna \\ Doctoral Student Of Bukhara State University, Bukhara, Uzbekistan
}

Journal Website:

https://theamericanjou

rnals.com/index.php/ta

jssei

Copyright: Original content from this work may be used under the terms of the creative commons attributes 4.0 licence.

\section{ABSTRACT}

The article analyzes the specifics of the ongoing reforms in the higher education system and reveals the importance of teacher-student relations in the development of national crafts. The main attention is paid to the unity of national folk crafts and traditions, and the legal normative documents adopted in our country in this regard are analyzed. Examples of national folk handicrafts of the Bukhara oasis are given, and trends in its development are revealed.

\section{KEYWORDS}

Crafts, customs, teacher-student system, values, methodology.

\section{INTRODUCTION}

It is known that at a time of rapid integration and globalization in the social, economic and spiritual spheres, special attention is paid to strengthening the content and scientificmethodological base of training competitive teachers in accordance with international qualification requirements, the use of innovative educational technologies.

In particular, the adopted international legal instruments, including the United Nations Universal Declaration on Higher Education in the XXI Century [1], the UNESCO Program Document on Higher Education Reform and Development [2], ensuring the uniformity of the quality of European higher education institutions. The Bologna Declaration has played an important role in improving the quality of education worldwide.

According to the main official features of higher education, it meets the standards recommended by the International Standard Classification of Education (ICSE), adopted by 
the General Conference of UNESCO in 1997. According to these documents, it is important to improve the competence of future teachers by raising the content and quality of higher education to the international level, the introducing advanced teaching methods using modern pedagogical and information and communication technologies.

Uzbekistan's desire to join the modern industrial world has necessitated the creation of a higher education system capable of adapting to the needs of the rapidly changing labour market. There is a need to strengthen competition, which encourages the development of higher education institutions and the provision of quality educational services by them.

In this regard, setting priorities for the systemic reform of higher education in the Republic of Uzbekistan, raising the process of training highly qualified personnel with modern knowledge and high moral qualities, modernization of higher education, social and economic development based on advanced educational technologies The Decree of the President of the Republic of Uzbekistan No. PF5847 "On approval of the concept of development of the higher education system of the Republic of Uzbekistan until 2030" [3] plays a key role in the development of industries.

\section{MATERIALS AND METHODS}

Professional skills play a key role in the training of competent personnel in the higher education system. It should be noted that from time immemorial, our ancestors paid great attention to training young people in a certain profession, to work in the system of teachers and students, to bring them up diligently. It is known that labour is the main criterion of human life. Through hard work, a person makes a living, finds a place in society, acquires high moral qualities, and finally attains greatness. Diligence is the ability of a person to use his talents, abilities, abilities, to work for himself and his loved ones, for the development of the Motherland, the nation, to meet their material and spiritual needs, to constantly improve their skills and experience.

According to statistics, there are more than 50,000 professions in the world, which are based on the needs and requirements of mankind and serve to meet them.

A person who has a profession displays such qualities as an honest bite, humanity, diligence, high morality, generosity. It should be noted that, of course, national education plays a key role in the professional development of our youth.

During the years of independence, systematic measures have been taken to restore and develop the national handicrafts. Including,

- Craft development centres were established in cities and districts with a wide range of folk crafts and creative traditions;

- Unique types of handicrafts have been revived and further developed;

- Market infrastructure for the supply of handicrafts to consumers has been formed;

- Exports of handicrafts were encouraged;

- Presentation of national handicrafts at exhibitions and fairs abroad.

Our state and government are committed to the development of national handicrafts, folk 
arts and crafts in our country, thereby fully preserving the rich cultural heritage and historical traditions of our people, providing employment to the unemployed, especially youth, women and low-income families. normative legal acts are being adopted.

In particular, the Decree of the President of the Republic of Uzbekistan dated November 17, 2017 No PF-5242 "On measures for further development of handicrafts and comprehensive support for artisans" [1]; Resolution of the President of the Republic of Uzbekistan dated November 28, 2019, No PP4539 "On additional measures for further development of crafts and support of artisans" [2]; The Decree of the President of the Republic of Uzbekistan dated June 30, 2020 PF-6017 "On measures to radically reform the state youth policy in the Republic of Uzbekistan and bring it to a new level" [3] was published for this purpose.

It should be noted that systematic measures are being taken in the country to develop national handicrafts, to continue the tradition of "Master-Apprentice". These measures are aimed at the following tasks:

- Restoration of forgotten folk crafts;

- Coordination of the activities of folk masters, craftsmen, specialists in applied arts, creative youth, acting on the basis of the traditions of folk applied art, regardless of the form of ownership;

- Creation of an environment of mutual cooperation and free competition between them, protection of their rights and legitimate interests;

- Implementation of social, cultural and educational goals, the satisfaction of spiritual and other intangible needs;
- Material and moral incentives, social protection of gifted children and youth;

- Carrying out charitable and sponsorship activities [4-7].

Crafts centres of each oasis have long been formed in Uzbekistan. From ancient times in Bukhara Sharif the direction of national folk handicrafts is very developed. Gold embroidery has a special place in the Bukhara system of handicrafts. This type of craft was revived in the gos of the XX century. Its formation dates back to long historical periods. According to written sources and the findings of archaeologists, goldsmithing was one of the leading forms of urban crafts. In the late 19th and early 2oth centuries, Bukhara was the centre of goldsmithing, and this profession was mainly practised by men. The women in the family helped them. Over the course of historical development, goldsmithing has gradually become a female art [8 - 13].

It is noteworthy that customs have a special place in the system of national folk crafts. When a teacher teaches a profession to a student, of course, he also explains the traditions and values that underlie this profession. So, if you want to know about any profession, of course, traditions play a key role in the history of its origin.

\section{CONCLUSION}

At present, great attention is paid to the specialization of the regions of the republic in the field of handicrafts and the attachment of diplomatic missions of the Republic of Uzbekistan abroad. The Embassy of the Republic of Uzbekistan in the People's Republic of China, the Embassy in the State of Israel and the Embassy in the Republic of 
Indonesia are attached to the Bukhara region. This is of great importance for Bukhara folk handicrafts to take their place in the world. In higher education, it is necessary to pay attention to these issues in the development of methods for improving the relationship between national folk crafts and traditions. Understanding the unity of national crafts and traditions is important in the development of national self-awareness and the creative abilities of students.

\section{REFERENCES}

1. United Nations Declaration on Higher Education in the 21st Century: Approaches and Practical Measures. Paris, October 9, 1998.

2. Reform and development of higher education. Program document. - Paris: UNESCO Publishing House, 1995.

3. Decree of the President "On approval of the Concept of development of the higher education system of the Republic of Uzbekistan until 2030" dated October 8, 2019 No. DP-5847.

4. Azizhodzhaeva N.N. (2006). Pedagogical technologies and pedagogical skills. T. $160 \mathrm{P}$.

5. Кенжаева, Х. П., Тожиев, Ф. И., \& Жураев, Б. Н. (2014). Роль женщин в создании и развитии демократического общества в Узбекистане. In Инновации в технологиях и образовании. рр. 119123.

6. Кенжаева, Х. П. (2021). Аёллар ижтимоий фаоллигини оширишда фуқаролик институтларининг ўрни. Scientific progress, 1(6), 957-961.
7.
Кенжаева, Х. (2021). Миллий маънавий меросимизда таълим-

тарбия масалалари. Общество и инновации, 2(6/S), 18-24.

8. Пардаева, М. А. (2021). Ўтмиши шарафли, келажаги буюк халқ маънавиятида хазрат алишер навоий қарашларининг ўрни. Инновации в педагогике и психологии, 4(3).

9. Pardaeva, M. D. (2020). The role of the jadid's thinking views in the fight against enlightenment against ignorance. Ўтмишга назар журнали, 10(3).

10. Пардаева, М. А., Узбекистан, Р., \& Голди-Скотт, М. Р. (2020). Реформа школьного образования в Узбекистане: переосмысление методики обучения и оценки. ISBN 978-5-9929-0917-3๔ ОГУ имени ИС Тургенева, 2020๔ МОО «Академия информатизации образования», 2020๔ Коллектив авторов, 2020, 25.

11. Pardayeva, M. D. (2020). "Lazerlar va ularning turlari” mavzusini innovatsion usullarda o'qitishning afzalliklari. In Молодой исследователь: вызовы и перспективы (рр. 722-724).

12. Пардаева, М. Д. (2018). Использование средств народной педагогики в воспитании толерантности у молодежи. Проблемы педагогики, (6 (38)).

13. Djuraeva, D. D., \& Berdiyeva, Z. M. (2016). Cultural heritage as a factor of human development (on the example of Uzbekistan). Ученый XXI века, 23. 